\title{
Fielding Dawson's "Certain Overflow Willingness"
}

\section{Charlotte Gafford}

"Call me Fee," he might have said, for he stood like Melville's Ishmael, strange to the overcast dusk of E. 19th Street where he has lived many of his Manhattan years. His head was not thrown back and he was not laughing, as in a photograph he once seemed to like for book jackets. Fielding Dawson was taller and grayer than I had expected; his looming figure seemed almost generative of the sidewalk's splotchy chiaroscuro. It was misting a little. No one had umbrellas.

Instead of the Melville opener (and he is a Melville man), Fielding spoke my name and led me through the wrought iron street gate, up stairs to the loft where he and Barbara live. There was my friend, his wife Barbara, darkly beautiful in an aroma of simmering borscht, with a bouquet of onions, parsley, and salad greens on the kitchen table before her. It was the beginning of a night $I$ remember as high key, like the reds and cadmiums of Fielding's paintings and collages hung around the room. It had come about because Seymour Krim introduced me to Barbara Dawson some months before, or at least had her look me up when she was on a temporary child-psychology consultant's job in Alabama. She invited me to visit them in their loft, to meet Fielding, to see their Franz Kline memorabilia the next time I was in New York City. This was it, but not one of those set-up interviews with tape recorder and questions stemming from the interviewer's having done the usual homework.

We had no trouble conversing, Fielding and I; in fact, we were not as thoughtful of Barbara as we might have been in our duet for hours over wine and a wonderful dinner and after-dinner drinks until dawn at Max's Kansas City. At the time I had read only two Dawson works: An Emotional Memoir of Franz Kline (Pantheon, 1967) and The Black Mountain Book (Croton Press, 1970). At least I had read two, which is more than most Kline devotees could say of the first published book, not to mention the New York literary vigilantes who missed in both works the onslaught of an intrepid newcomer to American letters.

The Kline Memoir, now lamentably out of print, is filled with youthful homosexual anxieties for the late painter and all kinds of sublimated searching for a father figure. It also offers close-up after close-up of Kline: at Black Mountain College (where he taught and where Fielding Dawson was a student from 194953), at the old Cedar Bar in Manhattan, in the company of his wife, among his peers of that most exciting period in American painting (the late 50's/early 60's era of Kline, deKooning, Pollock, Tworkov, Guston, Motherwell, et al.). Further, Memoir is one of those unabashed pieces of writing which are supposed to have died out with Thomas Wolfe (an admitted early influence, still evident in the crescendo passages in Dawson's fiction). There is something indeed intrepid about a writer who dared to refer to himself as a "jeun Telemachus." Perhaps Dawson anticipated a current generation which feels akin to the "jeun Tele- 
machus," always seeking in an interior search what the absent father chases, outward bound in the name of victory/voyage, Odysseus/Ahab.

This is not to suggest that Dawson simply foresaw the current nostalgia craze in fiction and film. What should be noted, from Dawson's earliest works on, is his particular proclivity for binding memories with dreams, blending the so-called real and unreal into heightened actuality. Young readers on campuses are turning on to Dawson (look, Fee, it's happening; and we all know what the young continue to do for writers such as Gibran, Hesse, Kafka-what a threesome!).

The Black Mountain Book is a good place to begin a chronological reading of Fielding Dawson. Those were the days, the Black Mountain ones, where students learned from Kline about the "field" of painting and from Charles Olson about the projectivist's "field" of poetry. If Kline was Dawson's Odysseus-father, so Olson was his Ahab-captain. MAXIMUS. It seems appropriate to see in Dawson's first two published works of "non-fiction" a prediction of his adherence in later "fiction" to the Jamesian definition of the novel, in "The Art of Fiction," as "a personal, a direct impression of life." Is this an inappropriate moment to recall also the Jamesian idea of life as all "inclusion and confusion," a "thick jungle"? I think not.

Somewhere between fiction and non-fiction lies the irrelevant answer as to whether Dawson's later books are autobiographical or fictional. No such line of demarcation is ever plumb; everything verbal and numerical (from quips to flipcharts) is in part fictional, personally assumptive or publicly speculative, just as every painting is, from reality, abstract. Krazy Kat/The Unveiling \& Other Stories, 1951-1968 (Black Sparrow Press, 1969) and Open Road (actually Dawson's first novel, finished in 1961 but unpublished until 1970 by Black Sparrow) are "personal, direct impressions of life." He remembers with the precision of a trompe l'oeil painter; every time the reader turns a page, what is remembered is exactly what the reader subconsciously anticipated and expected to be vivified with language. Now how can this come from a writer brought along by painters such as Kline and Tworkov, poets such as Olson and Creeley, whose work is calligraphed with ultimate-and sometimes seemingly selfish-privacy? I do not know the answer. I am not even certain that the question "applies."

Nonetheless, in Dawson's work (and I have read all of it now: the big-house, small-press, and pamphlet pieces), there is the expressionist recalling and elucidating private symbols and memories and dreams. Sometimes the thrust of his energy, the Eros, the force of whatever the hell Life is about, all but zaps the reader out of his chair. There is a conceptualized and heard graceful movement through calendar time and linear transition. His dynamics are painterly and musical; he uses repeats as a painter or a composer. There are assonance and dissonance in his language, in his remembering, in his pauses, his punctuation. Here is "form organic," as opposed to "form mechanic"-or plot. Fielding Dawson would no more contrive a plot to thread through his fiction than a ballplayer (Fielding himself) would hold on third base for an outfield fly with two away. 
As a teacher, I experimented with a Freshman English class last year at University College, University of Alabama in Birmingham, using Dawson's stories in The Dream/Thunder Road (Black Sparrow, 1972). The class took off on its own in group discussions and came up with occasionally bewildered but always joyous responses. Examples: "Dawson shows that life exists in dreams. He tries to relate the life in dreams with all its mass confusion to real life." And, "the author reflects the past as he felt at the time, with the objective viewpoint of his present mind." "He writes like he's talking to himself. Or to me." I do not necessarily subscribe to the "out of the mouths of babes" platitude; I simply concur with the reaction of those students.

Reviewing The Mandalay Dream (Bobbs-Merrill, 1971), I compared the novel to The Last Picture Show as filmed by Bogdanovich. When the kid in The Last Picture Show is run over, it is only sad to the point of bathos. But when the streetcar hits the kid in The Mandalay Dream and drags him through a city block of snow and darkness, it's you-and me. And when, inside his woolly cap, the blood crusts to mandalay (or pilgrim brown, as some painters call that particular color), it's our blood. It settles over the pain which provokes and perpetuates whatever we are, keeps us sometimes sane and sometimes mad in all those memories of having dreamed and sung of Rangoon or Mandalay.

It strikes me that the students and I were saying the same thing. I read them Dawson's short The Greatest Story Ever Told: A Transformation (Black Sparrow, 1973). They were as quiet as catechumens before an archbishop. At the end, there is a scene in which the narrator (Dawson) and his school chum Mac are at Sportsman's Park in St. Louis for a game between the Cards and the Giants; the empathic tension in my classroom at this point moved my voice to the tremor of pre-tears. That remarkable scene triple-counterpoints ballgame reportage with the narrator's telling Mac about having laid a particular high school girl while Mac interjects all the usual teen-age interjections, and the narrator silently remembers:

Then, I actualized-suddenly consciously in the crowd under the blue midwestern sky, her direct eyes, her pasty face, her toughness, and the durability of her effect on me and my consciousness of all of it, God, and this because in the most real sense she had given me the world.

As "Slaughter slammed a liner into right, and Musial scored." The language is simple, sometimes even mundane, but always right. The crescendo is Saxon syntax doing it as only Saxon syntax can. No curlicues, no embellishments, just laying it on word by word from a foundation of well-remembered and gutsy truth.

Perhaps it was Dawson's departure from youth-oriented situations which got him in mild critical disfavor with A Great Day for a Ballgame (Bobbs-Merrill, 1973). But how can an author be too disfavored by people who have never done him many favors? A Great Day is an older person's love story, an honest and totally valid emotional triangle which consists of a New York writer, his editor, 
and her young son. "Champagne for Everybody-This One's on God," Dawson tells us. This novel is, however, no place to begin the reading of Fielding Dawson, any more than The Hamlet is a wise starting point for a new Faulkner reader. The body of a major writer's prose deserves the same conditioning on the part of the reader that it has received from the author. I had thought of answering an especially insensitive review of A Great Day in The New York Times. Instead, it seemed more pertinent to attempt some assessment of the output of Fielding Dawson in toto to date. With this in mind one murky October night in 1973, I wrote to Fielding and said, "Fee, how about some words about just how, looking back, you feel that projectivist theories happened to stay in your psyche?"

"For Christ's sake," he answered. And then he told me.

He said that his earliest influence was William Saroyan, "which right away brought me into the focus of an emotional honesty including the risk of sentimentality (which I didn't care about, I was such an emotionally loaded youth), and also Thomas Wolfe, who expanded and continued that. At 19 yrs, in July \& August of 1949 , at Black Mtn. College, in a class taught by Charles Olson, I was introduced to Paterson 1 \& 2 and also the shorter and earlier poems [of William Carlos Williams], and that gave me a direction and a use of my ear-a discipline-which I've never lost."

Attributing this first most important influence on his adult work to Williams, he mentioned Pound. "Pound was the key to my scholarship. The other writers who really made a definitive impact were D. H. Lawrence, Rimbaud, and Melville. I actually didn't need Olson (Melville scholar) in that (although my critics might not believe that, that statement, the truth is simple: it was Mary Caroline Richards who got me reading Melville). And once begun (Moby Dick), I needed no encouragement. But my felt personal discovery of The Confidence Man left Olson a little bewildered (this all at Black Mountain College), and the proof of the Melville influence is in an essay I wrote on New American Fiction ... . So some eleven or twelve years after having read The Confidence Man, you'll see the impact Melville's definition of fiction made on me . . . 'at bottom, more real than reality.' Those words being the personal definitive impetus for my writing, and possibly the catalyst in that it threw me WAY ahead of myself. And back then at school, with Olson lecturing on just about everything as we read our own stories and poems and he too read his (which we criticized, though not much, as we were clearly aware of his force, an altogether original forcevision-backed by his having listened to Pound), and also there was Creeley, and brilliant students like Ed Dorn, and later John Weiners, etc."

It is not surprising that Dawson's first influence was primarily from the poets. "I know," he wrote to me, "as best a prose writer can, how poets read, what poets read, and how they pursue what it is they want in the manner of their thinking. That's the ear and mind at work (mine), in lieu, from an original awe, of what they put into print. So that makes Black Mountain a formidable chunk of experience, kin to childhood, the Army, and New York (Kline called Black Mountain downtown Manhattan).” 
When Dawson turned thirty, he quit painting and "turned completely to language," although he did drawings and collages for book covers, etc. He remembered that Olson had once said, "the poem catches you by the nose and pulls you along, you follow." He was aware of Kline working that way too: "drawn into it, so I became increasingly aware-accumulatively aware-that my work lay ahead of me, I mean that the end of whatever I attempted lay ahead of me in that I was imbued with it, and the stories from about 1951 to 1966 reflect that haunting and frightening awareness which with the completion of every story, was wonderfully rewarding."

It was at this time, Dawson recalled for me, that he began to doubt metaphors, "saw them as bridges over the dangerous areas, which were the emotional areas, so the handwriting was on the wall and I didn't know what to do. My writing began to be fragmented and compulsive as I was so frightened of what lay ahead; this first appears in a story called, 'The Invisible Glass,' but the end of the metaphor came in a long story called, 'Thread' [both in Krazy Kat]. And in personal unhappiness and a real sense of desperation I wrote the Kline Memoir. That meant, in a real sense, I gave up my style of fiction-writing, and having no place to go ahead with the metaphor, I went into myself in fact: no metaphors, and pure emotion. The Black Mt. Book followed, and then The Mandalay Dream, and A Great Day for a Ballgame, The Greatest Story, etc. . . . so I realized, and wouldn't recommend this process to anyone, that what lay ahead of myself was not only my so-called myself, but all the experimental matter within, so, still being pulled ahead, I went into-and back into-myself (no ego trip, this!), and in so doing I began to get to know myself, and respond personally inwardly as I had rarely responded to anyone outwardly, much less myself. The using of my own name in the narrative-something which no longer startles me, and in fact I'm getting weary of it in the way middleaged people say Well I've done that, what's next...."

Somewhere along the way, he read Chandler and Hammett (in whom he later noted the powerful use of monosyllabic words in declarative sentences). "They gave me a first person-a first person I hadn't had, and that liberating acceptance had the effect of opening a great big door, because when I used the third person my prose was metaphorical, and as I came to understand, my 1st person was not, because I was being emotionally honest and needed no metaphor."

Such a statement calls to mind Alfred Kazin's saying of Moby Dick:

The book grows out of a single word, "I," and expands until the soul's voyage of this " $\mathrm{I}$ " comes to include a great many things that are unseen and unsuspected by most of us. And this material is always tied to Ishmael, who is not merely a witness to the story . . . but the living and germinating mind who grasps the world in the tentacles of his thought.

("Ishmael and Ahab," 1956; reprinted in Contemporaries)

Fielding Dawson also discovered through writing his Black Mountain Book "the meaning of punctuation. Double quotes were world, single quote was personal- 
world, and no quotes at all a combination of the unspoken, known, potentially extra-sensory voice(s) and also as in the fashion of one speaking to oneself. My newest story, consciously using this, The Miracle [Black Sparrow, 1973], reveals, I think, the results. The two men almost being one person. As an inner dialogue." This quality of oneness is also evident in A Great Day in many passages.

Near the end of his letter to me, Dawson referred to "the so-called jungle of the inner self" as a jungle but also "a place where the unexpected comes into view. Along with little stuff like quotes and italics [which, he had told me earlier, "could hold the voice of potential rage, and the past"], naturally, comes a lot of emotional violence, and the suspense between the unexpected vehemence of feeling old suddenly! and the working of the art at best is a tightlipped love mixed with wild passion to do it, and a self loathing previously unfelt. No fun.

"But, hatefully enough, it's clear. Like suicide. And dawn.

"And he gives a sigh, it's lonely, because nobody else is hearing it so, and tho a cliché, a man alone in orginality understands he is mad by that which he hears and sees. I'm glad there's Rimbaud."

Yes, there is Rimbaud. There will always be Rimbaud. But there is also Dawson. His three sections from a novel, A Capitol Ship, illustrate the theories and practice of Fielding Dawson as artist/carver of "the simple yet intricate scene" on that old yo-yo called Life. He carves, as the Philippine yo-yo man carved, with "flickering fingers and quick wrist-turns."

He outlines our memories and dreams as John Hook "outlined the action we knew by heart anyway, but it was to hear him and watch him that was the thrill of before action, and in delight's envy, a certain overflow willingness . . .."

Reading Fielding Dawson imparts to the sensible reader the bulwark of sensibility which props up all human beings.

The sun was in its place, in the afternoon, and just to check up on myself, I figured I'd take a look at the sun dial, even though I knew what it would say, but I loved the feeling of being right, so I did . . . . The triangle and the disc were beautifully mottled: green bronze, and the projected razoredged shadow, rested neatly there between the Roman numeral 4, and 5 which in spite of daylight savings the sun had already told me.

"Uncle Charley"

One might speculate that Fielding Dawson has not given up the metaphor, but along with his work, has become it. As we all do, must-in one way or another. It has something to do with Creation, some say. 